\title{
A magyar légoltalom megszervezése az 1930-as években
}

DOI : 10 31627/RTF XXIV 2014 35-36-37-38N 75-84P

Az I. világháború alatt végrehajtott légitámadások tanulságai, a repülőtechnika gyors fejlődése, a légi háborúval kapcsolatos új katonai elméletek (mindenek elött az olasz Giulio DOUHET tábornok totális légi háborúra vonatkozó koncepciója) azt mutatták, hogy a jövő háborújában a légi erők tevékenysége az ellenséges országok egész területére kiterjed. Nemcsak a frontvonal és a katonai objektumok, hanem a hátország és a polgári létesítmények is légitámadások célpontjává válnak. A nagyvárosokra, közlekedési csomópontokra, ipartelepekre, mért csapások súlyos gazdasági és ellátási zavarokat idézhetnek elő, jelentős fegyveres erőket vonhatnak el a frontról a hátország védelmére. Az állandó veszélyérzet, a bizonytalanság komoly hatást gyakorolhat a lakosság hangulatára, ami társadalmi elégedetlenséghez, politikai feszültségekhez vezethet. Mindez egyre nagyobb hangsúlyt adott a hátország légi védelme megszervezésének, és ezen belül, az „aktív”, fegyveres légvédelem és a „passzív”, polgári légvédelem (más szóhasználattal: a légoltalom) kiépítésének is. ${ }^{1}$

Az 1930-as évek közepéig a világon 51 országban született légvédelmi törvény, ami a légi veszélyeztetettség fokozódását, és egyben a probléma felismerését mutatta. A Népszövetség leszerelési bizottsága 1932-ben maga is felhívta a figyelmet, arra hogy a nemzetközi egyezmények nem képesek garantálni a polgári lakosság biztonságát egy fegyveres konfliktus időszakában, ezért minden országban hathatós önvédelmet kell kiépíteni a légitámadások ellen. ${ }^{2}$

Magyarország esetében különös jelentősége volt a polgári légvédelem kiépítésének. Az ország légi veszélyeztetettsége az európai átlagot jóval felülmúlta. A kis terület és a nagyvárosok, gazdasági gócpontok határ közeli fekvése miatt az ország a legkedvezőtlenebb adottságú államok közé tartozott Európában. A trianoni Magyarországot — a korabeli gépek teljesítményét figyelembe véve — a kisantant államok légi kötelékei észak-déli irányban 30 perc, kelet-nyugati irányban 70 perc alatt átrepülhették. Az ország 10 legnagyobb városát (Szolnok kivételével) 10 percen belül elérhették az ellenséges repülők, alig adva időt a riasztásra. Györ, Miskolc, Debrecen, Szeged és Pécs 5 percnél rövidebb repüloútra feküdt a határoktól, így ott különösen nagy volt egy légi rajtaütés veszélye. A trianoni békediktátum nemcsak a támadó fegyverzet tartását tiltotta, hanem bizonyos védelmi fegyverek és eszközök (honi vadászrepülők, nagy kaliberü légvédelmi lövegek, gázálarcok) beszerzését, gyártását, rendszerbe állítását is korlátozta. ${ }^{3}$

A szomszédos államok jelentős légierővel rendelkeztek. Csehszlovákia 1933-ban 550 gépet, Jugoszlávia 630 gépet, Románia 500 gépet tudott hadrendbe állítani. A katonai fejlesztések felgyorsulása nyomán 1937-ben Csehszlovákia már 1300 géppel, Jugoszlávia 900 gépel, Románia 600 gépel rendelkezett. A szakemberek szerint a kisantant államok egy közös hadmüvelet keretében, egyetlen bevetéssel 280 t bombát dobhattak volna magyar célpontokra. Számolni kellet még a Szovjetunióval is, amely 1935-ben katonai segélynyújtási szerződést kötött Csehszlovákiával. A szovjet légierő 4000 géppel rendelkezett az európai térségben, ebböl Kijev és Harkov körzetében 500-500 gép állomásozott, készen arra, hogy szükség esetén csehszlovákiai repterekre települve bekapcsolódjanak a kialakuló fegyveres konfliktusba. ${ }^{4}$

Az 1930-as évek elején a polgári légvédelem megalapozása során főként az elméleti témák terén történt jelentősebb előrelépés. A szakmai előkészítő tevékenység, az alapelvek kidolgozása, a katonai és polgári légvédelem egyes feladatköreinek pontos meghatározása megfelelő alapot teremtett a polgári légvédelem (légoltalom) gyakorlati kiépítésének megindításához. A gazdasági válság azonban évekre visszavetette a szükséges anyagi eszközök, az intézményi háttér és a szervezeti keretek megteremtését. A müködőképes polgári légvédelem kiépítéséhez egyelőre hiányzott négy meghatározó elem - az átfogó törvényi szabályozás, az operatív vezető szervek felállítása, a szükséges anyagi fedezet biztosítása, és a polgári végrehajtó szervezet létrehozása. ${ }^{5}$

\section{A légoltalom központi szerveinek és jogi szabályozásának megteremtése}

A magyar honi légvédelem gyakorlati megszervezése érdekében 1933. V. 1-jén a Magyar Királyi Honvédelmi Minisztérium intézkedést adott ki az Országos Légvédelmi Parancsnokság (felállítására. Az Országos Légvédelmi Parancsnokság feladatkörébe tartozott a honi légvédelem kiépítésének, fejlesztésének, valamint a polgári légoltalom megszervezésének adminisztratív és szakmai irányítása, anyagi és személyi feltételrendszerének kidolgozása, a végrehajtás szabályozása és ellenőrzése, a honi légvédelmi szervek vezetése, valamint a légvédelmi képzés és a lakossági propaganda. Az országos légvédelmi parancsnok Magyar Királyi Honvédelmi Minisztérium osztályvezetői hatáskörrel rendelkezett és a katonai föcsoportfönökön keresztül volt alárendelve a honvédelmi miniszternek. Az Orszá- 
gos Légvédelmi Parancsnokság egyszerre töltött be parancsnoksági és hatósági funkciókat. A szükebb törzs június 15-én kezdte meg a munkát, saját szervi határozványai kidolgozásával. A teljes körü müködésre csak az átvezénylések és hatásköri kérdések tisztázása után, novembertől került sor, a végleges elhelyezést, irodákat és a szükséges felszerelést decemberben kapta meg az Országos Légvédelmi Parancsnokság. ${ }^{6}$

Az országos légvédelmi parancsnok feladatkörét 1933. VIII. 1. és 1935. V. 1. között MILOSEVICS Dezső tábornok, 1935. V. 1. és 1937. VIII. 15. között pedig RUSZKAY Jenő tábornok látta el. Az Országos Légvédelmi Parancsnokság vezérkari fönöke 1933 és 1935 között RÁKOSI Béla vkszt. ezredes, 1935 és 1937 között ADAY (ADELMANN) János vkszt. őrnagy volt. ${ }^{7}$

A polgári légvédelem kiépítésének egyik sarkalatos pontja az átfogó jogi szabályozás megteremtése volt. Az 1935-ben megszülető légvédelmi törvény kimondta, hogy a polgári légvédelem szakmai irányítója, operatív vezetője és ellenőrzője a honvédelmi miniszter, aki ezt a jogát az Országos Polgári Légvédelem szervezetein keresztül gyakorolja. ${ }^{8}$ A személyes honvédelmi kötelezettség alapján minden 14 és 60 év közötti lakos igénybe vehető légoltalmi feladatokra (kiképzés, gyakorlat, szolgálat). Ezek ellátása során úgy kell tekinteni, mintha a polgári személyek is katonai szervezet tagjai lennének. A jogszabály lehetővé tette, hogy a légoltalom érdekében rendkívüli rendszabályokat vezessenek be, szükség esetén korlátozzák a lakosság szabad mozgását. A Magyar Királyi Honvédelmi Minisztérium írta elő, hogy mely településen, milyen objektumok esetében, milyen jellegü és mértékủ védelemre van szükség, milyen létesítményekröl, felszerelésekröl kell gondoskodni. A törvény szigorú büntetéseket helyezett kilátásba a légoltalmi rendelkezések megsértőivel szemben. Aki gondatlanságból komolyabb közveszélyt okozott, 5 évig tartó, aki pedig szándékos szabályszegéssel idézett elö ilyen helyzetet, 15 évig tartó fegyházbüntetést kaphatott. Különösen súlyos esetben a bíróság akár halálbüntetést is kiszabhatott. ${ }^{9}$

A keret jellegủ légvédelmi törvény részletes rendelkezéseit az 1936-ban kiadott végrehajtási utasítása tartalmazta. ${ }^{10}$ A légvédelmi kötelezettség által érintett lakosokat két csoportba sorolták. Az egyik csoportot a katonai légvédelem személyi kiegészítésére behívottak képezték - döntően hadvagy katonaviselt férfiak, akik lehetőleg valamilyen speciális, főként müszaki képzettséggel rendelkeztek. Ezek légvédelmi képzése katonai irányítás mellett történt, és elsősorban az országos figyelöszolgálatban kerültek alkalmazásra. A másik csoportot a polgári légoltalom segélyosztagaiba besorolt lakosság jelentette. Öket a helyileg illetékes légoltalmi vezetés választotta ki, és képezte ki. A tanfolyamokat a lakóhelyen szervezték. Figyelembe vették az érintettek foglalkozási körülményit, nők esetében a családi kötelezettségeket is. Nőket, és a 18 év alatti korosztályt, a cserkészeket, leventéket föleg kisebb fizikai megterhelést jelentő beosztásokban, egészségügyi, híradó és irodai feladatokra alkalmazták. $^{11}$

A légoltalmi szempontok helyet kaptak a tüzrendészet fejlesztéséről szóló törvény paragrafusai között is. ${ }^{12}$ A jogszabály elöírta, hogy a tüzoltóságot fel kell készíteni a légitámadások okozta károk felszámolására, illetve, hogy a tüzoltó szervezet légvédelmi készültség idején a védekezést vezető katonai parancsnok irányítása alatt tevékenykedik. A törvény végrehajtási utasítása külön hangsúlyozta, hogy a tüzoltó kiképzés során nagy szerepet kell kapnia a légoltalmi tevékenységre való felkészítésnek. ${ }^{13}$ A rendelet rögzítette, hogy a tüzoltó testület a tűzvédelmen kívül más jellegü légoltalmi feladatokra is igénybe vehető (pl. müszaki mentés, kárfelszámolás stb.). Ugyancsak elöírták, hogy tüzoltóság kapcsolódjon be a légoltalmi segélyosztagok tüzvédelmi képzésébe. Mindezek a törvények, rendeletek megteremtették a magyar légoltalom kiépítésének jogi hátterét. Meghatározták a legfontosabb irányelveket, melyek alapján megindulhatott a részletek kidolgozása és a légoltalom gyakorlati megszervezése. $^{14}$

A polgári légvédelem kiépítésére vonatkozó fontosabb tudnivalókat, intézkedéseket tartalmazta az 1936-ban kiadott Légoltalmi Utasitás. A honi légvédelem, a tevékenység jellege szerint két feladatkörre oszlott. Az aktív légvédelem katonai tevékenység volt, ami az ellenséges légitámadások fegyveres megakadályozását, elhárítását szolgálta. A passzív légvédelem, a légoltalom a támadások hatását csökkentő megelöző, mentő és kárfelszámoló tevékenységre terjedt ki. A légoltalom körébe tartoztak mindazok a rendelkezések, létesítmények, felszerelések, eljárások, szervezetek és képzések, melyek az ellenséges támadások elkerülését, a személyi, anyagi és erkölcsi károk csökkentését, a bekövetkező rombolások mielőbbi helyreállítását szolgálták. ${ }^{15}$

A településeket a veszélyeztetettség mértékét, illetve a bekövetkező rombolások következményeit figyelembe véve három csoportba sorolták. Az „A” kategóriába olyan nagyvárosok, vagy politikai, gazdasági, katonai szempontból fontos kisebb városok tartoztak, amelyek elsődleges célpontja lehettek az ellenséges légitámadásoknak. „B” besorolást kaptak azok a városok, melyek nem számítottak fö- 
célpontnak, de gazdaságilag vagy katonailag fontos objektum, település közelében helyezkedtek el, így másodlagos célpontok lehettek, és a támadásuk jelentős erkölcsi vagy anyagi kárral járhatott. „C” kategóriába került az összes többi 10000 főnél több lakosú város és község. Külön légoltalmi egységként szerepelt a „Légoltalmi Budapest”, ami a fövárost, illetve a körülötte lévő 6 megyei várost (Újpest, Kispest, Rákospalota, Budafok, Pestszentlőrinc, Pestszenterzsébet) és 17 községet fogott össze. Az odacsatolt községek száma később tovább bővült. ${ }^{16}$

Gazdasági és társadalmi szerepük szempontjából három csoportba sorolták az egyes építményeket, intézményeket, vállalatokat is. Az országos jelentőségü intézmények, valamint a 400 legnagyobb vállalat és ipartelep az I. légoltalmi csoportba került. Ezek védelmét közvetlenül az Országos Légvédelmi Parancsnokság szervezte és irányította (az illetékes vegyesdandáron keresztül). A helyi jelentőségü intézmények, hivatalok, iskolák, illetve üzemek, raktártelepek, ahol 100 fö körüli jelenlévővel lehetett számolni, a II. légoltalmi csoportba kerültek. Ezek, a település légoltalmi szervezetének alegységeit képezték, védelmük megszervezéséről a helyi közületi légoltalmi vezető gondoskodott. A III. légoltalmi csoportba a nagyobb tömeget nem koncentráló, komolyabb közösségi funkcióval nem rendelkező létesítmények kerültek, melyeknél a lakóházakra érvényes szabályokat kellett követni.

A légoltalmi közületek élén légoltalmi vezető állt, aki általában az adott település közigazgatásának vezető tisztviselője volt: törvényhatósági jogú és megyei városokban a polgármester, a megyékben az alispán, azokban a községekben, amelyek járási székhelyek voltak a föszolgabíró, más községekben pedig a jegyző. A légoltalmi vezető az országos szabályozás alapján kiadta a végrehajtáshoz szükséges helyi rendelkezéseket, megszervezte a közület polgári légvédelmét. Irányította a légoltalmi szervezet felállítását, gondoskodott a védelmi terv kidolgozásáról, az előírt létesítmények elkészítéséről, a szükséges anyagok és felszerelések beszerzéséről. Intézkedett a légoltalmi szolgálatra igénybe vett lakosok kiválasztása és kiképzése ügyében, ellenőrizte a közülethez tartozó II. és III. csoportos létesítmények felkészülését. A légoltalmi vezető mellett, a napi (főként adminisztratív) teendők ellátását „A” besorolású településen légoltalmi ügyosztály, „, $\mathrm{B}$ ” és „,C” osztályú településen légoltalmi előadó végezte. ${ }^{17}$

A légoltalmi vezető munkáját szakmai kérdésekben a légoltalmi bizottság segítette. Ennek tagja volt az Országos Légvédelmi Parancsnokság megbízásából az illetékes vegyesdandár kiküldött közege és a közbiztonsági teendőket is ellátó országos rendvédelmi testületek (rendőrség, csendőrség) vezetői. Helyet kaptak benne az egyes szakterületek vezető tisztviselői (a tüzoltóparancsnok, a tisztiorvos, a főmérnök, a számvevőség vezetője), a meghatározó társadalmi szervezetek képviselői (Légoltalmi Liga, Vitézi Szék, Vöröskereszt, stb.). Közremüködtek a munkában a Magyar Allamvasútak, a Magyar Királyi Posta, a Magyar Hajózási Részvénytársaság helyi irányítói, a közművállalatok vezetői és a nagyobb ipartelepek illetékesei. A bizottság szükség esetén más szakembereket, más szervezetek képviselőit is felkérhette a részvételre. Az alispán, mint megyei légoltalmi vezető nem rendelkezett közvetlen szervezési feladatokkal (csak a megyeháza vonatkozásában), hanem elsősorban ellenőrző jogkört gyakorolt az illetékességébe tartozó települések légoltalmának kiépítése felett. A járási főszolgabíró csak a járás székhelyén szervezte tevőlegesen is a védekezést, a többi községben ellenőrző jogkört gyakorolt. ${ }^{18}$

A helyi légoltalmi végrehajtó szervezet irányítását a légoltalmi parancsnok látta el, aki általában a Magyar Királyi Csendőrség, vagy a Magyar Királyi Rendőrség helyi vezetője volt. Ahol nem volt jelen a rendőrség vagy a csendőrség, ott a légoltalmi vezető, vagy egy másik katonaviselt személy (rendszerint a köteles vagy önkéntes tüzoltóság parancsnoka) töltötte be ezt a posztot. A vármegyének nem volt légoltalmi végrehajtó szervezete vagy parancsnoka. A légoltalmi szolgálat: megelőző egységekből (figyelő, riasztó, gázfelderítő, kárfigyelő), mentő osztagokból (tűzoltó, mentő, müszaki mentő), kárfelszámoló alakulatokból (müszaki helyreállító, légoltalmi munkás), valamint segédosztagokból (légoltalmi törzsek, hírrendszer, futárszolgálat, segédrendőrség) állt.

A lakóházak önvédelmének szervezését a felállítás alatt lévő Légoltalmi Ligára bízták. A 10 lakónál többel rendelkező épületekben lakóház légoltalmi őrséget kellett szervezni, amely a legalapvetőbb tűzoltó, mentő, helyreállító és rendfenntartó feladatokat látta el. A házi örség parancsnokát a lakók közül választották ki. Erre a feladatra nőket is kijelölhettek. A 10 lakónál kisebb épületeket, több szomszédos lakóházzal együtt légoltalmi épülettömbbé szervezték, és közös őrséget állítottak fel. ${ }^{19}$

Az Országos Légvédelmi Parancsnokság a légoltalom országos kiépítésére vonatkozó intézkedéseit a 7 vegyesdandár útján valósította meg. A dandár légvédelmi parancsnokának feladatkörébe tartozott a saját körzetében a légvédelem és légoltalom megtervezése, kiépítése, irányítása és ellenőrzés. Az 1930-as évek közepén azonban még csak az 1. (budapesti) vegyesdandárnál rendszeresítettek ilyen beosztást. A többi körzetben a légvédelmi tüzérség rangidős parancsnoka látta el ezeket a feladatokat. Az Országos Légvédelmi Parancsnokság 1936-tól sürgette, hogy a többi vegyesdandárnál is mielőbb 
kerüljön kinevezésre légvédelmi parancsnok. A légvédelmi parancsnoki törzsek felállítását elsősorban a 2. (székesfehérvári), az 5. (szegedi), és a 7. (miskolci) vegyesdandárnál tartották volna fontosnak, tehát a legveszélyeztetettebb határszakaszok térségében. Egyelöre azonban ezeknél az egységeknél is csak egy-egy légvédelmi előadói beosztást létesítettek, ugyanúgy, mint a 3. (szombathelyi), a 4. (pécsi) és a 6. (debreceni) vegyesdandárnál. ${ }^{20}$

Már 1934-ben megkezdődött a honi légvédelmi jelentő és riasztó szolgálat felállítása, melynek szolgálati utasítását 1935-ben adta ki az Országos Légvédelmi Parancsnokság. A szabályozás szerint a légvédelmi figyelőrendszer katonai irányítás alatt állt, de adatokat szolgáltatott a katonai légvédelem és a polgári légoltalom számára egyaránt. A figyelőszolgálat aktivizálására a légvédelmi készültség elrendelésekor került sor. A figyelőhálózat két együttmüködő szervezetből állt, az országos légvédelmi jelentő szolgálatból és a helyi polgári légoltalmi figyelő és riasztó hálózatból. ${ }^{21}$

Az országhatárok mentén legalább 170 örs felállítására volt szükség, hogy a figyelőszolgálat elérje a megfelelőnek tartott 7-8 kilométerenkénti sürüséget. A hézagmentes megfigyeléshez három ilyen vonalat kellett volna kiépíteni egymás mögött. Az optimális 510 örs felállításához azonban nem álltak rendelkezésre a szükséges anyagi és személyi feltételek. Ezért az a döntés született, hogy a határon egyelöre egysoros vonalat építenek ki, és a fontosabb települések, gazdasági gócpontok körül külön figyelő hálózatot állítanak fel, összesen 250 őrs telepítésével. A légvédelmi figyelő őrsök a jelentéseiket 60 szárnyközpontba továbbították, ahonnan, összesítés után továbbküldték az információkat a Kerületi Légvédelmi Központnak (Kerléköz). Az ország területét a 7 vegyesdandár illetékességi körzetének megfelelően 7 légvédelmi kerületre osztották. A Kerléköz nemcsak összesítette a befutó jelentéseket, hanem ki is értékelte azokat, és feldolgozott formában juttatta el az Országos Légvédelmi Központnak (Orléköz). A szárnyközpont és a Kerléköz az országos katonai jelentő és riasztó szolgálattól adatai mellett megkapta és feldolgozta az egyes települések polgári figyelő örseinek jelentéseit is. ${ }^{22}$ (I.sz. melléklet)

Eredetileg a rendszer személyi szükséglete 4198 fó volt, ezt azonban, részben a honvédség létszámkorlátaihoz való alkalmazkodás, részben pedig takarékossági szempontok miatt 2618 före csökkentették. Az alapfelszerelés és a kiképzés költsége így is $1185776 \mathrm{P}$ volt. Az országos figyelöhálózat feltöltése, müködőképes állapotba hozása 1936 nyarán kezdődött. Ekkor indult meg a kiválasztott személyzet központi kiképzése. Az őrsök jelentéseinek biztonságos és gyors továbbítására, és az információk könnyebb feldolgozása érdekében 1936 őszén a Haditechnikai Intézet kifejlesztett egy speciális távbeszélő készüléket, amely lehetővé tette a különböző adatok (ellenséges gépek száma, repülési iránya, magassága stb.) kódok segítségével történő gyors továbbítást. ${ }^{23}$

Az Országos Légvédelmi Központ elhelyezésére a Gellért-hegy nyugati fala alatt 1936-ban megkezdték egy bombabiztos létesítmény, a Sziklaközpont kialakítását. Itt kapott helyet az 1. (budapesti) Kerléköz is. A Honvéd Vezérkar Főnöke azt szorgalmazta, hogy az Országos Légvédelmi Parancsnokság számára is a közelben, lehetőleg a Sas-hegy belsejében készüljön hasonló létesítmény, hogy ne kelljen a Dunán átívelő (egy bombázás során könnyen megsérülö) híradó összeköttetést kiépíteni a magasabb parancsnokságok között. ${ }^{24}$

A légvédelmi riasztás elrendelése az „A” kategóriájú települések és az I. csoportos építmények esetén a Kerléköz, vagy a szárnyközpont feladatkörébe tartozott. A „B” és „C” besorolású települések riasztásáról a Kerléköz, illetve saját polgári figyelö őrseinek jelentései alapján, a helyi közületi légoltalmi parancsnok határozott. A II. és III. csoportos építményeket szintén a helyi hatósági légoltalmi szolgálat riasztotta. A légoltalmi riasztásnak 2 fokozata volt. A „légi veszély” elrendelése akkor történt, ha ellenséges gépek 15-20 percnyi távolságra voltak az adott településtől, objektumtól, és fennállt a légi támadás lehetősége. Ekkor úgynevezett csendes riasztást hajtottak végre. A „légi veszély” jelzés csak a légvédelmi és légoltalmi szerveknek szólt, hogy legyen idejük felkészülni a riadóra. A „légi riadó” kiadására akkor került sor, ha az ellenséges gépek már 5 percnyire megközelítették az adott települést. Ekkor már a lakosságot is riasztották, hogy mindenki elvégezhesse a légitámadás esetére elöírt feladatokat, és levonulhasson az óvóhelyre. A „légi veszély elmúlt” jelzést akkor adták le, amikor az ellenséges gépek már legalább 10 percnyi távolságra eltávolodtak a településről. Erről a lakosságot is tájékoztatták, hogy az emberek mielőbb visszatérhessenek a mindennapi tevékenységükhöz. ${ }^{25}$

\section{Lépések a légoltalom gyakorlati kiépítésére}

Az 1930-as évek második felében több nemzetközi konfliktus, köztük a japán-kínai háború vagy a spanyol polgárháború (Sanghaj, Nanking, illetve Barcelona, Guernica bombázása) figyelmeztető tapasztalatokkal szolgált, a sürün lakott nagyvárosok elleni légitámadások hatásairól. Ez újabb lendüle- 
tet adott az európai államokban a katonai légvédelem és a polgári légoltalom megszervezésének. Magyarországon, az alapelvek és a fontosabb jogszabályok kidolgozása, illetve a központi vezető szervezetek felállítása után a légoltalom gyakorlati kiépítése 1937-ben indult. Az Országos Légvédelmi Parancsnokság élére 1937. VIII. 15-én FÁBRY Dániel vkszt. ezredes került, a vezérkari főnöki posztot továbbra is ADAY János vkszt. őrnagy töltötte be. ${ }^{26}$

A hazai légoltalom fejlesztése terén fontos szervezeti intézkedés volt, hogy az Országos Légvédelmi Parancsnokság a honvédelmi tárca keretében önálló csoportfőnöki beosztást kapott, és ettől kezdve már nem a Katonai Föcsoportfönök, hanem közvetlenül a miniszter alá tartozott. Ezzel együtt átalakult és kibővült a feladatköre is. A Magyar Királyi Honvédelmi Minisztérium szakmai testületeként az Országos Légvédelmi Parancsnokság látta el az összes katonai és polgári légvédelmi szervezet legfőbb irányítását. Az Országos Légvédelmi Parancsnokság kezdeményezte, hogy a légoltalom kiépítése érdekében fontos tárcaközi együttmüködés koordinálására az Állandó Tárcaközi Bizottság keretében állítsák fel a légoltalmi albizottságot. A bizottság 1933 és 1935 között, a légvédelmi törvény elökészítése időszakában rövid ideig már müködött. Az egyes tárcák ezen keresztül állandó összeköttetésben állhattak egymással, gyorsabban reagálhattak a légoltalom megszervezésével kapcsolatban felmerülő aktuális kérdésekre, és minden érintett intézmény, főhatóság naprakész információkhoz jutott. Az Állandó Tárcaközi Bizottság légoltalmi albizottsága 1937 októberében ismét felállításra került. Vezetését az országos légvédelmi parancsnok látta el. ${ }^{27}$

A városokban 1937 elején megkezdődött a légoltalom helyi vezető szervezeteinek kiépítése. Felállították a légoltalmi bizottságokat, megkezdték a városi légoltalmi tervek kidolgozását, és a rendszer kiépítéséhez szükséges költségvetés összeállítását. Budapest székesfőváros föpolgármesteri hivatalában légoltalmi ügyosztályt szerveztek (XIV. üo.), ez foglalkozott a polgári légvédelem témájával. Budapestet 3 légoltalmi fökörzetre osztották. A budai az I-III. és a XI-XII. kerületet, a Pest északi az VVI. és a XIII-XIV. kerületet, a Pest déli pedig a IV. és a VII-X. kerületet fogta össze. A 3 fökörzet 14 körzetre, illetve 57 alkörzetre oszlott. Az ipari és hatósági légoltalom segélyosztagainak személyi feltöltéséhez a fövárosban összeírták az 1884-1888 között született férfiakat. A megjelentek 61\%-át minősítették alkalmasnak. Ipari légoltalmi szolgálatra 2360 föt, hatósági légoltalomra pedig 9810 fö́t jelöltek ki. Hamarosan kiderült azonban, hogy bizonyos feladatokra (tüzoltás, gázvédelem) az 50-55 éves korosztálynál fiatalabbakra van szükség, ezért pótsorozást tartottak az 1889-1893 között születettek számára. Ekkor írták össze a cserkészeket, leventéket is, akik a figyelő és riasztó örsökhöz, az egészségügyi szolgálatba vagy a törzsekhez kerültek beosztásra. ${ }^{28}$

Budapest hatósági légoltalma 1938-ban gyors fejlődésnek indult. Megépültek az első nyilvános óvóhelyek. Intézkedtek a lakóházak tüzvédelméről, meghatározták a szükséges tüzoltó felszerelés és oltóanyagok (homok, víz) mennyiségét, elhelyezését. A fóvárosban 35 légoltalmi segélyhelyet alakítottak ki, ahová a felhívások nyomán 1164 középiskolás (cserkész és levente) jelentkezett, légoltalmi egészségügyi szolgálatra. A Budapest Székesfővárosi Közmunkák Tanácsa 1937. I. 16-án rendelettel írta elö, hogy főváros belső, összefüggően beépített területein lakóházakat már csak törmelék, gáz és szilánk ellen védő óvóhely kialakításával együtt lehet építeni. ${ }^{29}$ Ezzel egyidőben a Magyar Királyi Belügyminisztérium felszólította a többi törvényhatóságot, hogy ennek megfelelően alakítsák át saját építési szabályrendeleteiket, és írják elő az óvóhely építési kötelezettséget. ${ }^{30}$

Az Állandó Tárcaközi Bizottság légoltalmi albizottsága 1937. X. 5-i ülésén külön foglalkozott a polgári lakosság gázálarccal történő ellátásával. A külföldi példák szerint, a nagyhatalmak és a szomszédos kisantant államok esetében is, a lakosság jelentős tömegei kapnak ingyen gázálarcot. Magyarországon azonban ez anyagi okok miatt megoldhatatlan volt. Ezért az a döntés született, hogy az állam a központi létesítmények légoltalmi szervezetét, a helyi törvényhatóságok légoltalmi szolgálatának cselekvő személyzetét és a lakóházi őrség tagjait látja el. A polgári lakosság többi része saját költségén szerezhet be önkéntesen gázálarcot. ${ }^{31}$

Az első riasztási gyakorlatokat országszerte 1937 májusában tartották. Ezeknek az volt a tapasztalata, hogy a harangszóval, kézi szirénákkal, gyári gőzsípokkal végrehajtott riasztás nem hallatszik megfelelően, ezért a beépített terület nagyságától függően központi vezérlésủ nagy teljesítményü elektromos szirénák beszerzésére van szükség. Számos probléma jelentkezett a nyár folyamán végrehajtott elsötétítési gyakorlatokon is. Kiderült, hogy a rögtönzött eszközökkel, házilag megoldott elsötétítés nem elég hatékony, ezért speciális felszerelésekre és megoldásokra van szükség ezen a területen is. Általános jelenség volt, hogy a lakosság még nem érezte át a légoltalom jelentőségét, a gyakorlatok során bevezetett korlátozásokat inkább bosszantó kellemetlenségként élte meg. Rendkívül fontos volt tehát a légoltalmi felvilágosítás és propaganda további fokozása. 
Jelentős mértékben bővült a légoltalmi szakirodalom és a lakosságnak szánt ismeretterjesztő, tájékoztató, mozgósító, populáris kiadványok száma. A Tüzrendészeti Közlöny mellékleteként már 1935 júniusában megjelent a Polgári Lég- és Gázvédelem címü szakmai lap, amely elsősorban a hátország ellen várható légitámadások veszélyeire, és az ellenük való védekezés módjaira hívta fel a figyelmet. A Budapesti Nemzetközi Vásáron az Országos Légvédelmi Parancsnokság által szervezett légoltalmi kiállításnak 1936-ban 100 000, 1937-ben 130000 látogatója volt. 1937 júliusában országosan megkezdődött a közalkalmazottak légoltalmi oktatása, a posta, a vasút, a köz- és magánüzemek alkalmazottainak felkészítése. Szeptemberben megindult a légoltalmi segélyosztagok tagjainak szakmai képzése. A közvélemény figyelmének felkeltése érdekében a rádióban 1938 februárjától heti negyedórás müsort iktattak be, ahol a légoltalom egy-egy témakörét ismertették, közérthető, gyakorlatias formában. $^{32}$

Az ország légoltalmi helyzetének átfogó felülvizsgálatára az Országos Légvédelmi Parancsnokság, a 7 vegyesdandár légvédelmi közegeivel és különböző társadalmi szervek bevonásával 1937 októberében több napos légoltalmi gyakorlatot szervezett. Budapesten október 13-14-én tartottak riasztási próbát. Nagyszabású légoltalmi ellenőrzésre került sor a következö évben, november végén és december elején, amikor minden törvényhatósági jogú város és számos más település területén, repülögépek bevonásával harcszerü légoltalmi gyakorlatokat tartottak. A légoltalmi végrehajtó szervek bomba- és vegyi támadás okozta károk elhárítását gyakorolták. ${ }^{33}$

Már az 1930-as évek közepén felmerült, hogy a polgári légvédelem megszervezéséhez szükség lenne egy országos társadalmi szervezetre, amely a lakosság figyelmének felhívásával, légoltalmi felvilágosító munkával és az önvédelemre való mozgósítással segítené az állami szervek tevékenységét. A szervezés 1937 nyarán indult. A Légoltalmi Liga hivatalos megalakulására 1937. XII. 5-én került sor, a Vigadóban rendezett ünnepség keretében, melyen a kormányzó is megjelent. A Légoltalmi Liga elnökévé HABSBURG József királyi herceget, a felsőház véderőbizottságának elnökét választották. Az alelnöki posztot FÁBRY Dániel vkszt. ezredes, az Országos Légvédelmi Parancsnokság vezetője, az ügyvezető igazgatói teendőket PETRÓCZY István ny. repülő ezredes, a fôtitkár feladatkörét TEASDALE Ottó tüzoltó másodföparancsnok látta el. ${ }^{34}$

A Légoltalmi Liga müködési költségeit a Magyar Királyi Honvédelmi Minisztérium részéről juttatott támogatás (1938-ban $100000 \mathrm{P}$ ), a 2 pengő éves tagdíj, valamint a társadalmi adományok fedezték. A Légoltalmi Liga országos szervezete 1938 nyarára épült ki. A légvédelmi kerületeknek megfelelően a Légoltalmi Liga is kerületi szervezeteket hozott létre, melyek élén egy-egy nyugállományú tábornok állt. A helyi szervezetek anyagi és erkölcsi támogatását a Magyar Királyi Honvédelmi Minisztérium a helyi közigazgatás kötelességévé tette. 1939-ben a központi költségvetés már csak 50000 pengőt utalt át a Légoltalmi Liga céljaira, mert a rendelkezésre álló anyagi eszközök zömét a katonai légvédelem kiépítésére fordították. 1939. I. 30-án a Légoltalmi Liga keretében külön női bizottság alakult, a kormányzó feleségének fővédnöksége mellett, Anna királyi herceg asszony elnökletével. A női csoport feladatkörét elsősorban az elsősegélynyújtó képzés és a felvilágosító propaganda képezte. ${ }^{35}$

A légoltalom megszervezése terén komoly előrelépést jelentett, hogy az 1938. III. 5-én meghirdetett győri program jelentős anyagi forrásokat biztosított a honvédelem fejlesztése számára. Ennek keretében a légoltalom kiépítésére 24 millió pengőt fordítottak.

A nemzetközi feszültségek kiéleződése és a magyar revízió megindulása nyomán 1939-ben már egyre fontosabbá vált a légoltalom teljes körü kiépítése, és bevethetővé tétele. Ehhez, az adott helyzethez igazodó új szabályozásra volt szükség. A kiadásra kerülő új honvédelmi törvény megtartotta az 1935-ös jogszabályban rögzített főbb alapelveket, de szélesebb körủ és részletesebb rendelkezéseket tartalmazott. ${ }^{36}$

A magyar légoltalom megszervezése eltért más európai országok (Németország, Olaszország, Jugoszlávia, Szlovákia) mintáitól. A szervezet nem volt a hadsereg vagy a rendőrség része, és nem is félkatonai milíciákra vagy politikai mozgalmakra épült, hanem széleskörü társadalmi részvétellel müködött. Az új szabályozás jelentősen megnövelte a légoltalom önállóságát. A szakmai irányítás, illetve a végrehajtás ellenőrzése változatlanul a Magyar Királyi Honvédelmi Minisztérium kezében maradt, de nagyobb szerepet kapott benne a Magyar Királyi Belügyminisztérium is. Kibővültek a légoltalom feladatai, hatáskörét kiterjesztették a települések és építmények légi támadással szembeni védelmét szolgáló összes tevékenységre, módszerre, eljárásra. Ez egyben a felelősség és terhek növekedését is jelentette. Az eredményes müködéshez szükséges minden szervezeti, anyagi, személyi és felszerelésbeli feltételt magának a légoltalomnak kellett biztosítania. ${ }^{37}$

A törvény kiterjesztette a védelmi kötelezettséget a 10000 főnél kevesebb lakosú településekre is. A gazdasági, igazgatási vagy katonai szempontból fontosabb községek számára felállították a „D” légoltalmi osztályt. Szélesítették az érintett lakosság körét. A személyes légvédelmi kötelezettséget 60-ról 70 évre emelték. Az iskolákban már 10 éves kortól bevezették a légvédelmi felvilágosítást, amit 14 éves kortól a légoltalmi feladatok ellátására felkészítő képzés követett. 
Az új törvényhez új Légoltalmi Utasitás-t kellett volna összeállítani, mert a korábbit már túlhaladta az idő. A légoltalom kiépítésének felgyorsítása és a menetközben felmerülő problémák rugalmas megoldása érdekében azonban a kormány úgy határozott, hogy egyelőre nem adnak ki átfogó utasítást, hanem az egyes területeken felmerülő aktuális kérdéseket a Magyar Királyi Honvédelmi Minisztérium rendeleti úton szabályozza. Az 1939. VI. 17-én kiadott első ilyen rendelkezés hatályon kívül helyezte a korábbi Légoltalmi Utasitás-t, és korszerübb intézkedéseket vezetett be a légoltalom megszervezése terén. ${ }^{38} \mathrm{Az}$ addiginál nagyobb hangsúlyt kapott a légoltalmi közületek együttes fellépése. Intézkedtek a kölcsönös segélynyújtás megszervezésére a szomszédos települések között, de ilyen együttmüködést alakítottak ki a településeken belül a légoltalmukat önállóan szervező I. csoportos létesítmények, ipartelepek és a hatósági légoltalmi szolgálat között is. ${ }^{39}$

Megkezdődött a községek légoltalmának kiépítése. A kisebb településekböl községcsoportokat alakítottak, közös védelmi szervezettel, egy nagyobb településsel a központban. A közületeket a légoltalmi terv elkészítése mellett külön készültségi és riadóterv kidolgozására utasították, hogy szükség esetén a védelmi szervezet azonnal aktivizálható legyen. Nagyobb hangsúlyt kapott a lakóházi légoltalom. A lakóépületekben csak 20 fő esetén rendelték el önvédelmi őrség felállítását, de ezek a létszám és a felszerelés bővülésével már jóval hatékonyabb müködésre voltak képesek. A 20 lakónál kisebb házakat a szomszédos épületekkel házcsoportokba szervezték, és közös légoltalmi őrséget állítottak fel. A ház és házcsoport légoltalmi parancsnokok és helyetteseik hivatalos intézkedési jogkört és központi kiképzést kaptak. ${ }^{40}$

Az 1939-ben kiadott Magyar Királyi Honvédelmi Minisztérium rendeletek újraszabályozták a légoltalmi csoportba sorolás kritériumait. Átalakították és bővítették az I. és II. csoportba tartozó létesítmények körét. A II. légoltalmi csoportba került szinte minden számottevőbb közintézmény, ipari és kereskedelmi egység. A III. csoportba gyakorlatilag csak a lakóházak tartoztak. A közületek 5 évre szóló légoltalmi fejlesztő programot készítettek, és ehhez 5 éves költségvetési tervet állítottak össze. 1939. VII. 1-jén felülvizsgálták az I. légoltalmi csoportba sorolt ipartelepek védelmi felkészülését. Megállapították, hogy az ipartelepek 90\%-a megfelelö felkészültséggel rendelkezik a riasztás, az elsötétítés, a tủzvédelem, a légoltalmi szolgálatosok egyéni és szakfelszerelése tekintetében. A legnagyobb problémát a hiányzó óvóhelyek jelentették. Az ipartelepeknek csak 50\%-a rendelkezett minden tekintetben megfelelő védelmi létesítményekkel, a többi csak a szükségszerű szintet érte el. ${ }^{41}$

A lakossági önvédelem fejlesztése érdekében a Magyar Királyi Honvédelmi Minisztérium rendeletben kötelezte az összefüggően beépített területen lévő, 20 lakónál többel rendelkező régi építésủ házak tulajdonosait, hogy egy éven belül alakítsanak ki elöírás szerinti szükségóvóhelyet, és szereljék fel meghatározott mennyiségủ tűzoltó, elsősegélynyújtó és romeltakarító eszközzel. ${ }^{42}$ A légoltalmi létesítmények elkészítéséhez a kormányzat 50\%-os mértékü, adóleírásban érvényesíthető segélyt nyújtott, a maradék 50\%-ra pedig alacsony kamatozású hitelt biztosított. A végleges óvóhelyek kiépítését $1942-$ re tervezték. A nagy anyagi költségek, az építőanyag és a felszerelés hiảnya miatt azonban a megadott időre a tervezett létesítményeknek csak egy része készült el ${ }^{43}$

Tovább bővítették a légoltalmi felvilágosítást és a szakmai kiképzést. A tájékoztatás és mozgósítás egyik legfontosabb eszközének számított a Légoltalmi Liga Riadó című lapja (szerkesztő: NAGYRÉVI-NEPPEL György), és a melléklete, a Légoltalmi Közlemények (szerkesztő: BORSÁNYI Julián hmtk. százados). Ez utóbbi 1939-től már önálló folyóiratként jelent meg. A Riadó a lakosság szélesebb rétegei számára készült, a Légoltalmi Közlemények elemzőbb szakmai írásai, technikai tájékoztatói, jogszabály-magyarázata pedig inkább a légoltalom szervezésében és aktív végrehajtásában közvetlenül résztvevőknek szólt.

Budapesten a Légoltalmi Liga 1005 légoltalmi tanfolyamot szervezett, amelyeken 98768 fő vett részt. Ebből $58 \%$ a fövárosban, $42 \%$ pedig a légoltalmi szempontból Budapesthez sorolt megyei városokban és községekben került megtartásra. Ezen kívül a légoltalmi ház és házcsoport parancsnokképző tanfolyamon 69036 fö, női légoltalmi tanfolyamon 9002 fó, egészségügyi és elsősegélynyújtó képzésben 6873 fö, házi túzoltó képzésben 3843 fö, egyéb képzéseken 6260 fó vett részt. Budapesten 1939 augusztusáig összesen 193782 fö kapott légoltalmi kiképzést, a fóváros lakosságának 11\%-a, illetve a hozzá tartozó települések népességének $14 \%$-a. ${ }^{44}$

1939. VIII. 24-én a német-lengyel konfliktus kiéleződése, és a román mozgósítás nyomán, Magyarországon is részleges mozgósításra és a légoltalmi készültség elrendelésére került sor. A Lengyelország ellen szeptember 1-jén meginduló német, majd szovjet támadást a magyar légvédelmi szakemberek fokozott figyelemmel kísérték, de már a hazai lakosság is egyre nagyobb érdeklődést tanúsított a légi háború hírei iránt. A lengyelországi háború friss légügyi tapasztalatait is felhasználva 1939. október végén többnapos országos légoltalmi gyakorlatra került sor. Október 22-én, vasárnap minden városban és 5000 fó feletti községben légoltalmi napot szerveztek előadásokkal, bemutatókkal. Október 23-án az összes iskolákban a tanórák keretében a légoltalom kérdéseivel foglalkoztak a tanárok. Ezt követően 48 órás harcszerü gyakorlatokra kerül sor, repülők bevonásával. A Magyar Királyi Honvédelmi Minisztérium nem közölte elöre mikor és hol rendelnek el légiriadót, így a légoltalmi szolgálatnak és a lakosságnak is váratlanul kellett alkalmazkodni egy imitált támadási helyzethez. ${ }^{45}$

Az 1939. X. 24-27. között megrendezett gyakorlatok során a magyar légoltalom a szükségszerü szinten müködött. Számos probléma akadt ugyan, föleg a technikai felszerelés, speciális eszközök és védelmi létesítmények elégtelensége miatt, a légoltalmi szervezet azonban az elvárásoknak megfelelö- 
en teljesített. A lakosság is fegyelmezetten és együttműködően vett részt a próbariasztásokon. A tapasztalatok azt mutatták, hogy a magyar légvédelem és légoltalom egy helyi jellegü, korlátozott idejü és léptékủ fegyveres konfliktus során várható légitámadások elhárítására, a veszteségek csökkentésére és a keletkező károk mielőbbi felszámolására — lehetőségeihez mérten — felkészült. A II. világháború első hónapjainak eseményei, a nagyvárosok ellen végrehajtott tömeges légitámadások tanulságai azonban arra figyelmeztettek, hogy a korábban még megfelelönek tartott felkészültségi szint már koránt sem elegendő. Jelentős lépéseket kell tenni a légoltalmi rendszer teljes kiépítésére és technikai korszerüsítésére, hogy egy nagyobb szabású légi háború kibontakozása esetén kellő módon teljesíteni tudja majd a feladatát.

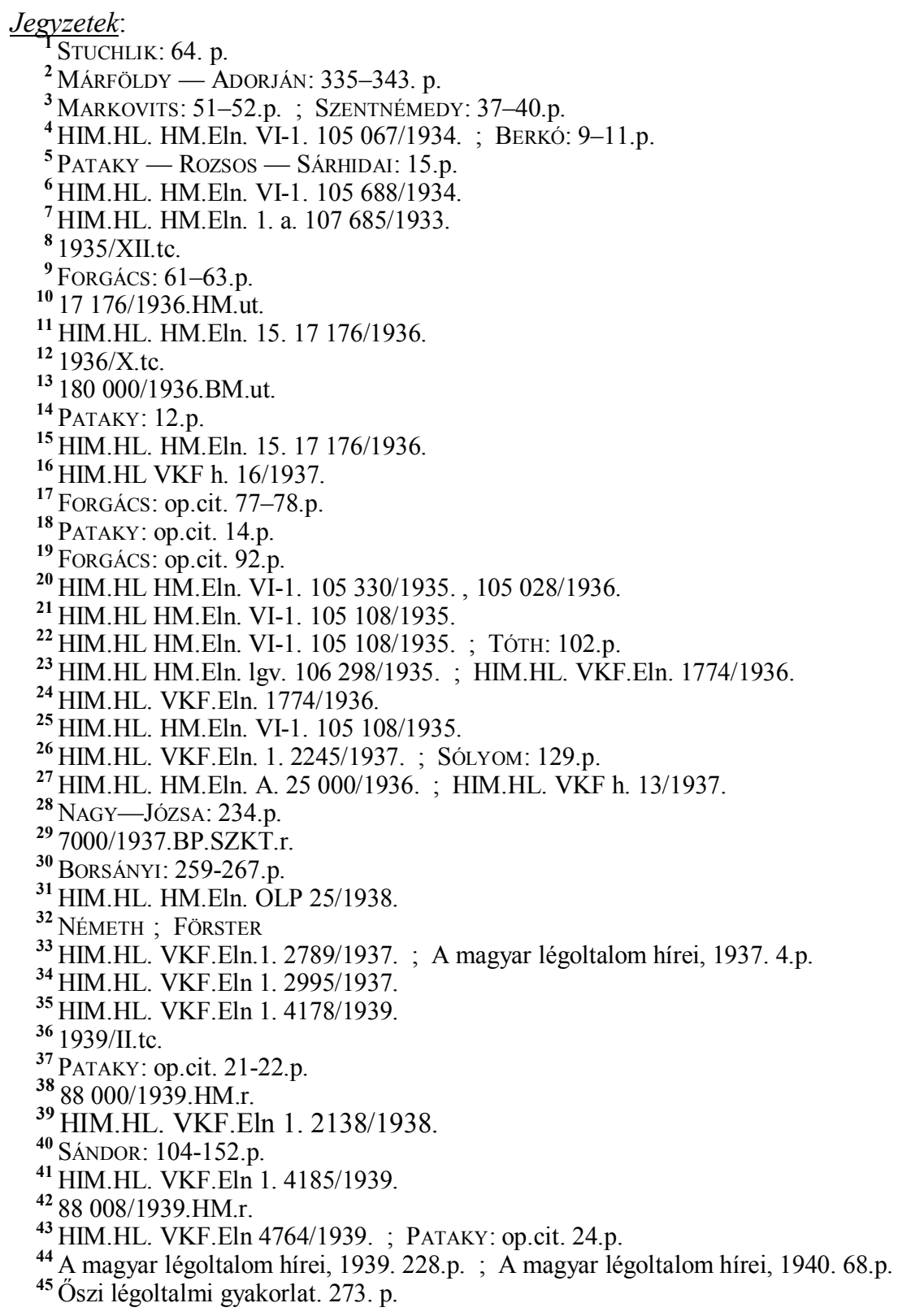

Jegyzetekben alkalmazott röviditések:

MONOGRÁFIÁK, KISMONOGRÁFIÁK ÉS HASONLÓ JELLEGÜ KÖTETEK

BERKÓ

ForGÁCS

FÖRSTER
BERKÓ István (szerk.): Légoltalmi ismeretek. Budapest, 1937, Országos Légoltalmi Parancsnokság. 477 p.

- Forgács József: Magyar légoltalom. Budapest, 1937, Arany Ny. 265 p.

- Förster Rezsö: A légoltalom magyar irodalma 1928-1938. Budapest, 1938, Stádium. 27 p. 
MÁRFÖLDY - ADORJÁN

NÉMETH

PATAKY

PATAKY — ROZSOS - SÁRHIDAI

SÁNDOR

TANULMÁNYOK

BORSÁNYI

MARKOVITS

NAGY-JÓZSA

SÓLYOM

STUCHLIK

SZENTNÉMEDY

TÓTH

\section{CIKKEK}

A magyar légoltalom hírei. 1937.

A magyar légoltalom hírei. 1939. 228.p.

A magyar légoltalom hírei. 1940. 68.p.

Öszi légoltalmi gyakorlat.
- MÁRFöldy Aladár - AdORJÁn János: A légi veszély és a védekezés módjai. Polgári szempontból tekintve. Budapest, 1936, Madách Könyvkiadó. $369 \mathrm{p}$.

— NÉMETH Ferenc: Légvédelem és a repülés szakirodalmi jegyzéke. Budapest, 1936, s.n. 32 p.

- PATAKy Iván: A magyar polgári védelem, légoltalom története 19351992. Budapest, 1992, Polgári Védelem Országos Parancsnokság. 138 P. HU-ISBN 9630333961.

- PATAKY Iván — RozSOs László - SÁRHIDAI Gyula: Légi háború Ma gyarország felett. I.köt. Budapest, 1992, Zrínyi Kiadó. 271 p. HU-ISBN 9633271541 .

- SÁNDOR András (szerk.): Légvédelmi rendelkezések. Budapest, 1940, Közigazgatási Könyvkiadó. 244 p.

- BORSÁNYI Julián: Védenek-e a lakóházak légoltalmi óvóhelyei? Légoltalmi Közlemények, II.évf. (1940) 17.sz. 259-267.p.

- Markovits Árpád: A hátország gáz- és légvédelme. Magyar Katonai Szemle, I.évf. (1931) 1.sz. 47-59.p.

— NAGY-JózSA György: Légoltalmi segélyosztagok. Riadó, II.évf. (1938) 8.sz. 233-235.p.

- Sólyom András: A spanyol polgárháború a légierők szempontjából. $M a-$ gyar Katonai Szemle, VIII.évf. (1938) 5.sz. 123-130.p.

- Stuchlik Imre: A passzív légvédelem. Magyar Katonai Szemle, 2. évf. (1932) 2. sz. 63-68. p

Szentnémedy Ferenc: Honi légvédelem. Magyar Katonai Szemle, II.évf. (1932) 7.sz. 29-40.p.

TóTH Elemér: A légvédelmi figyelö és jelentő szolgálat befolyása a légi hadmüveletekre. Magyar Katonai Szemle, VI.évf. (1936) 2.sz. 101-108.p.

— A magyar légoltalom hírei. 1937. Riadó, I.évf. (1937) 1.sz. 4.p.

— A magyar légoltalom hírei. 1939. Riadó, III.évf. (1939) 8.sz. 228.p.

— A magyar légoltalom hírei. 1940. Riadó, IV.évf. (1940) 5.sz. 68.p.

— O Öszi légoltalmi gyakorlat. Riadó, III.évf. (1939) 10.sz. 273.p.

\section{LEVÉL-, IRAT- ÉS DOKUMENTUMTÁRI GYÜJTEMÉNYEK}

HIM.HL.HM.

HIM.HL.VKF.

\section{JOGSZABÁLYOK}

1935/XII.tc.

1936/X.tc.

1939/II.tc.

7000/1937.BP.SZKT.r.

88 000/1939.HM.r.

88 008/1939.HM.r.

17 176/1936.HM.ut.

180 000/1936.BM.ut.
Hadtörténeti Intézet és Múzeum, Hadtörténelmi Levéltár, Honvédelmi Minisztérium Iratai.

— Hadtörténeti Intézet és Múzeum, Hadtörténelmi Levéltár, Honvéd Vezérkar Főnöke Iratai.

- 1935/XII.tc. a légvédelemről.

1936/X.tc. a tüzrendészet fejlesztéséről.

1939/II.tc. a honvédelemről.

7000/1937.BP.SZKT.r. a Budapest székesfőváros területére érvényes építésügyi szabályzat légoltalmi szempontból való kiegészítése. Budapesti Közlöny, LXXI.évf. (1937) 137.sz. 2-3.p.

- 88/1939.HM.r. a légoltalom megszervezése tárgyában. Honvédségi Közlöny, LXVI.évf. (1939) 25.sz. 175-203.p.

— $\quad 88$ 008/1939.HM.r. a lakóházi légoltalmi óvóhelyek létesítése és felszerelése tárgyában.

Budapesti Közlöny, LXXIII.évf. (1939) 286.sz. 2-5.p.

17 176/1936.HM.ut. a légvédelemről szóló 1935/XII.tc. végrehajtása tárgyában. HIM HL. HM. elnöki 15.osztály.

180 000/1936.BM.ut. a tüzrendészet újabb szabályozása. Belügyi Közlöny, XLI.évf. (1936) 42.sz. 725-808.p. 
A magyar légvédelmi riasztási rendszer az 1930-as években

I.sz. melléklet

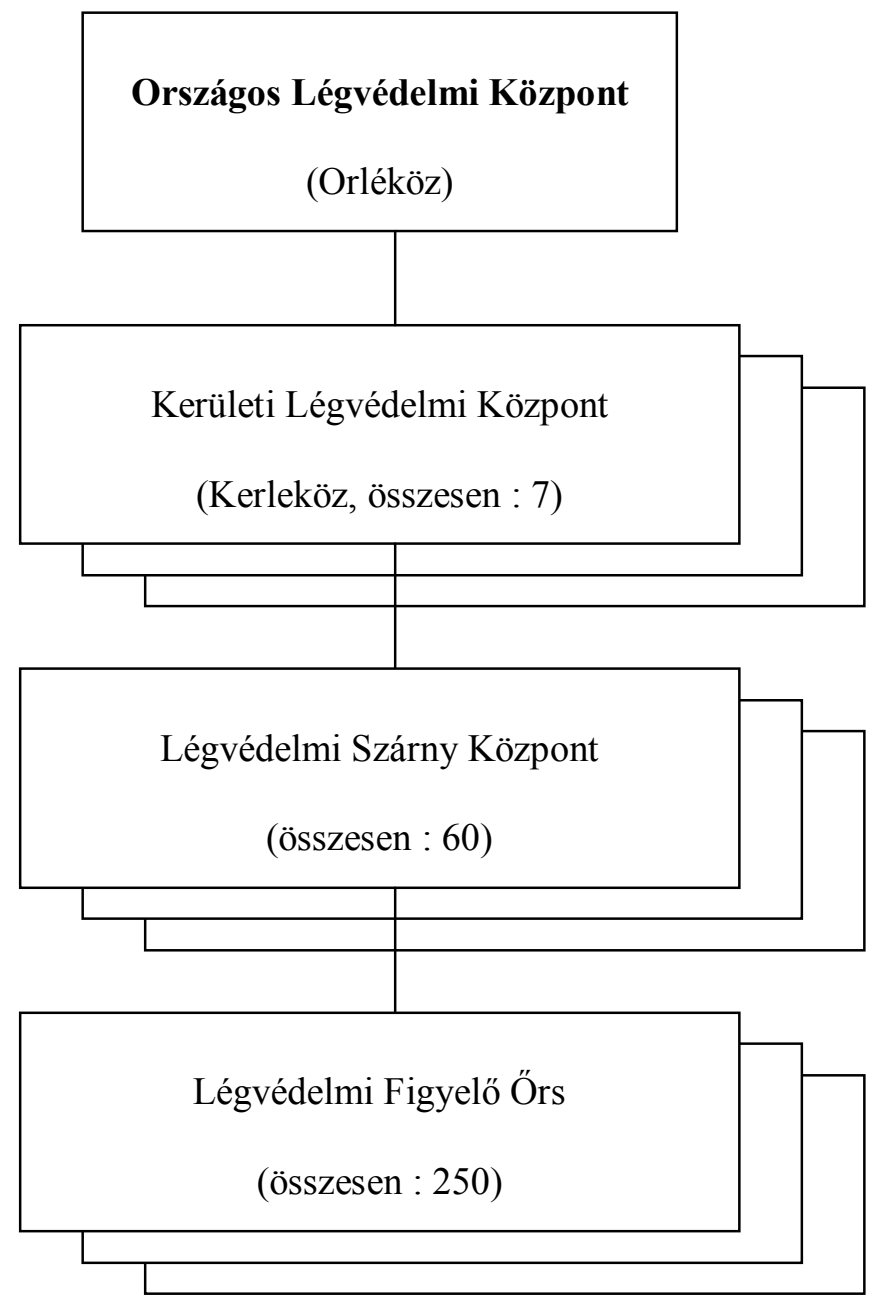

Forrás ! Tóтн Elemér: A légvédelmi figyelő és jelentő szolgálat befolyása a légi hadműveletekre. Magyar Katonai Szemle, VI.évf. (1936) 2.sz. 101-108.p. 